\title{
Developing Students' Financial Literacy and Financial Behaviour by Students' Emotional Quotient
}

\author{
Azizah Fauziyah, Siti Aty Ruhayati \\ Postgraduate School \\ Universitas Pendidikan Indonesia \\ Bandung, Indonesia \\ azizahfauziyah@student.upi.edu
}

\begin{abstract}
Indonesian financial level exists at the middle level to demand efforts to improve financial literacy and financial behaviour. This study aims to determine the effect of emotional capability to financial literacy and its implications for financial behaviour. This research is a descriptive study using multiple regression analysis. The study was conducted at Senior High School in two places with different characteristics as a moderating variable. This study used 120 respondents for each school and using simple random sampling. The results have shown that financial literacy is not enough to make financial decisions in terms of managing personal finances. It takes emotional quotient to make financial decisions which can eventually build the financial behaviour of students in terms of managing finances for consumption and saving habits. Based on the results of different test, the Senior High School which is located in the central of areas the craft (Tasikmalaya) have literacy and financial behaviour is better than the Senior High School of the tourist area (Cianjur).
\end{abstract}

\section{Keywords: Consumption, Emotional Quotient, Financial} Literacy, Financial Behaviour, Savings

\section{INTRODUCTION}

There is a significant attention on financial literacy issues caused by the shifting of economic environment. Recently, every country is facing a similar thread on deflation of financial literacy. A survey conducted by Otoritas Jasa Keuanggan (OJK) in 2016 revealed that the financial literacy level of Indonesia with the well rate criteria is only $21.5 \%$. This indicates a lower level of knowledge and understanding of the society regarding on financial literacy.

Moreover, several studies have also shown that a weakness of financial literacy had failed the economics' decision making because lack of adequate information [1]. Lack of financial literacy in the community is a systematic problem and has macroeconomic consequences clearly, thus it will influence on the person's financial behaviour [2][3][4].

Yii Shih and Cheng Ke [5] also investigated the implication of financial literacy on consumer financial behaviour with demographic variable as segmentation factor. They implied that consumer with highest financial literacy tends to be more responsible compared with the lowest consumer.

Those studies have highlighted how significant financial literacy as an approach to gain a positive financial behaviour. Consequently, certain exercise and training shall be established in the early stage of student development. Generally, a person will begin to learn the financial knowledge if there are pressured circumstances such as determining financial majors or for entering the workforce. In fact, the ideal age to learn on financial is at senior high school. This early stage of financial learns should take place on this stage as milestone for their further financial management [3].

The financial literacy introduction of the students is begun since entering Senior High School will keep students have the preparation, experience and knowledge which is expected to increase students' confidence in making financial decisions of the future. However, the increase in financial knowledge will not necessarily result in improved behaviour [6][7].

This issue is largely happened in Indonesia as many of student exiting in senior high school. The education curriculum regarding to financial knowledge is more than sufficient but in fact, such financial knowledge not corresponds with their financial behaviour. Knowledge is not enough to make this occurred and as discussed in this particular study, there is an urgency to improve their emotional capability as fundamental factor to refine their financial behaviour.

With this emotional quotient, students are able to know their own feelings and the others' that will guide a person's behaviour [8]) thus the collaboration between financial literacy and 
emotional ability are expected to improve the students' financial behaviour.

This study aims to determine the influence of emotional capability on financial literacy and its implication for financial behavior in senior high school in Tasikmalaya and Cianjur. The focus of financial behavior studied is about the student's behavior in consumption and saving considering both financial behaviors is often carried out by senior high school students. Through this study students are expected to use their other ability besides their intellectual ability to improve and maintain the financial behavior that has been previously possessed.

\section{LITERATURE REVIEW}

Financial management is defined as "an integral part of total management focusing on its task to manage finance"[9]. With such financial management someone is hoped to achieve one's personal satisfaction and his personal financial goal. According to financial management concept someone will only be "rich" as long as he able to organize his financial efficiently.

Senior high school student are familiar with concept of their daily and future consequences of their money or formally known as a personal concept of financial management, as explicitly define as management of daily consumption and savings. Walstad et al [10] and J.J Xiao [11] identified that the students' financial management as same as the financial behaviour which has the goal in order that the students can take the right financial decisions. The development of basic disciplines in terms of money management will be useful for students in the long run by doing financial behaviour consistently

Research shows that financial behaviour is influenced by the demands and available resources, e.g. knowledge, attitude, and personal traits [12]. Meanwhile, the other research has also revealed that a positive financial behaviour would have been progressing when there is knowledge and a good financial comprehension known as financial literacy[2][3][4].

Financial literacy is more than just knowledge and information. Otherwise. Financial literacy also describes the intelligence of a person's to use the information and resources. They are the key to achieve and maintain financial wellbeing [1][3]. Financial literacy can lead a person to make decisions regarding appropriate financial to minimize the financial consequences which will occur in the future[1][13].

Increasing the use of financial literacy is essential to improve the financial behaviour. Hogarth \& Hilgerth [13], Mandell [3], Borden et al [14], Yii Shih and Chen Ke [5] and Asaad [15] argue that a person with someone with a high financial literacy is believed to have financial behaviour better and can make financial decisions well and in accordance with the current economic environment thus he has a better financial results

In behavioural theory stated that the behaviour was not an outcome, but a part that integrated to contribute effectively in creating that outcome [16]. In order to generate a successful financial management requires $20 \%$ intellectual capability and $80 \%$ other factors including emotional quotient. Knowledge of finance does affect behaviour, but the knowledge factor itself will not be enough to make a person behave financial in accordance with the desired goals.

Emotional intelligence includes self-awareness and impulse control, persistence, enthusiasm and self-motivation, empathy and social skills. Such emotional quotient will also can delay individual satisfaction by proportionally plotting his/her emotion in accordance with ability to wisely choose the right choice with making a careful emotional considerations[17][8].

The research hypothesis proposed in this study is there are influence on significant emotional intelligence and financial literacy to improve financial behaviour. It is based on the premise put forward by Ludigdo [18] that "behaviour is not just a rationality problem (intelligence quotient), but it involves emotional and spiritual dimension in man".

\section{RESEARCH METHODOLOGY}

This research examines the emotional quotient and financial literacy as well as the effect on the students' financial behaviour. The independent variables in this study are the emotional quotient (X1); self awareness, self regulation, motivation, empathy and social skills, and financial literacy (X2) relating to knowledge and decision making based on the possessed knowledge. Besides, the dependent variable in this study is the financial behaviour $(\mathrm{Y})$ relating to students' skills in financial management, particularly for consumption and saving.

Based on the objectives and the variables stated above, this research is categorized as verification research. This study will test the hypothesis of the influence of emotional ability and financial literacy on the students' financial behaviour through a survey of Senior High School students at Tasikmalaya and Cianjur.

Meanwhile, survey explanatory is used as instrument to highlight student's emotional quotient, financial literacy, their financial behaviour and dominant impacting factor to establish both emotional quotient and financial behaviour

Population of this research is student of senior high school located in the city center of handicraft industry (Tasikmalaya), 
and Senior High School students located in the tourism area (Cianjur). The sample of this research consists of 120 respondents gained with simple random sampling technique. Data will be gathering by observation, interview and questionnaire and literature study. To analyze data, multiple regression test will be used to by using SPSS for window version 22.0 program. This regression test is applied to find out the influence of emotional quotient and financial literacy toward student's financial ability

Model equation that indicates the impact of emotional quotient and financial literacy toward financial behaviours is:

\section{Financial behaviour $=0,699+0,106$ Emotional Quotient + 0.635 Financial Literacy}

\section{IV.RESULTS AND DISCUSSION}

Based on the results of data analysis by using SPSS 22.0 program; t-test for emotional ability variable and financial literacy variable is 5.874 each and 4.487 , noticeably significant since the p-value of both t-test result had slightly lower than estimated $\mathrm{p}$-value or $0,000<0,05$. This result has indicated a positive and significant impact of emotional quotient and financial literacy toward financial behavior.

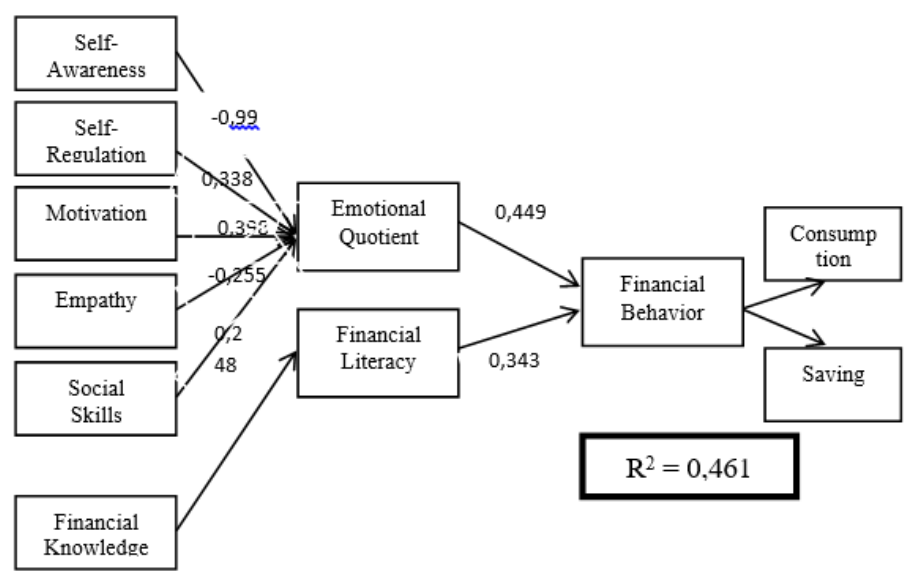

Figure 1. Data Result

Source: SPSS 22.0

This research discusses the emotional quotient and financial literacy and its influence on financial behaviour. The hypothesis testing results show that the statistic t-score for emotional quotient variable is 5.874 and the statistic t-score for financial literacy variable is 4.487 with p-value is $0.000<0.05$. Therefore, it can be concluded that the emotional ability which consists of self awareness, self regulation, motivation, empathy and social skills, as well as financial literacy related to knowledge and decision-making based on the possessed knowledge have positive influence on financial behaviour. The contribution of emotional quotient and financial literacy variable on the financial behaviour can be seen in the figure 1 .

Motivation and self controlling are indicators for emotional quotient. These two indicators has had larger loading factor compared with another indicators. According to simultaneous test, the value of estimated $\mathrm{F}$ was 49,970 considerably significant since the p-value below the level of significance or $0,000<0,05$. This $\mathrm{F}$ statistical test result had revealed a strong and significant influence of emotional quotient and financial literacy on student's financial behaviour. This result has also shown that these two variables have simultaneously impacted positively toward student's financial behaviour.

Due to financial behavior hypothesis accepted, this research proves the theory Ludigdo [18] that a behavior is formed not on the basis of intellectual ability alone, but a behavior that will encourage success if it goes with the possessed emotional ability. Someone will behave with all the feeling so that the behavior based on intellectual ability will be in accordance with the ethical and moral force.

The student preoccupied knowledge and comprehension over financial matter still inadequate to make them enhanced financially, especially when it comes to consumption and savings [6] [7]. With emotional quotient, student will be encouraged to control and reorganize their desires effectively and efficiently. In accordance to this research, it is obvious that emotional quotient that corresponds with self-regulation, motivation, student's social skill and financial literacy capable to refine student's financial behaviour e.g. Their budgeting for consumption and savings.

Contributions to the value of R2 based on the factor number loads between emotional ability and financial literacy are 0.461 or $46.1 \%$ and categorized into medium effect. Therefore, it can be concluded that the emotional ability and financial literacy have a significant effect on the financial behavior of the students, especially to improve the students' money management behavior in terms of consumption and saving.

Moreover, the paired sample test has also shown that there was significant differentiation of student's financial behaviour according to their homeland. The value of estimated $t$ was 6,318 considerably larger that the $t$ table. This paired sample test has exposed that student's financial behaviour within the Tasikmalaya handicraft region is relatively better than student who lives within Cianjur tourism area with the average score was $19,94>13,02$. 
Meanwhile, a paired sample test has also exposed that there were significant differentiation of student's financial behaviour according to their gender with the value of estimate $t$ test was 5,813 , with 0,000 . This result has also point out dominant of female over male in financial management with the average score $16,88>13,22$.

Knowledge and understanding of finance are not enough to make a change in financial behavior. Therefore, it takes selfcontrol, motivation, and social skills which can help the students to behave better in terms of managing their money. Besides, being able to optimize financial behavior, emotional intelligence can also delay individual satisfaction and put the emotions on the right portion related to selecting satisfaction and setting the $\operatorname{mood}[17][8]$.

\section{CONCLUSION AND SUGGESTION}

Based on the results of descriptive analysis and verified by using SPSS 22.0 program, it can be concluded that the factors that can build the student financial behaviour consists of financial literacy and emotional ability variable. Financial literacy and emotional ability variable have medium value in improving the students' financial behaviour. Financial literacy is not enough to make a person have a proper financial behaviour because knowledge is not enough to improve a person's behavior[6][7]. The indicators of emotional ability variables that have the highest score can build financial behaviour is a person's motivation. It is caused by the impulse within him to behave financial well related to management of his finance. Students also need a control themselves so they can delay individual satisfaction and put their emotions on the right portion related to selecting satisfaction and setting the mood [17][8].

Financial behaviour of the students is limited to the financial management like consumption and savings activities. Most students do not consume based on their needs, but based on their desire without thinking about the usefulness of a product or service to be consumed. Therefore, excessive consumer behaviour causes students poor ability to set aside their money for saving.

This research shows that the emotional ability consists of motivation, self-control and social skills. Besides, financial literacy which consists of financial knowledge has positive and significant effect on financial behaviour. Overall, the effort to improve the emotional ability and financial literacy is seen as a considerable effort to build a better financial behaviour than ever before. An application of other emotional ability consists of selfknowledge and empathy needs to be improved since it is an aspect that does not reach the ideal value. For the aspect of selfintroduction, the students can try to identify what their needs but intention. Besides, for the empathy aspect, the students must have an awareness of the feeling and concern for others so that they can use their money responsibility.

This research also shows that the financial behaviour of students who live in the craft center (Tasikmalaya) a better than the students who live in a tourist area (Cianjur). A financial behaviour is based on the surrounding environment, as well as the students who are in the craft center. They have an environment [5] [19] that is accustomed to doing good financial management on its effort to encourage the students to imitate the environment in terms of better financial management than ever before. In addition, the students with good financial behaviour are dominated by female students since their knowledge and ability to manage their finance better than male students. Knowledge of financial and emotional ability possessed by female students is better resulting improvement in financial behaviour.

The students need conductive environment where they can create responsible financial behaviour so that the students have preparation, and knowledge to manage their finance [20][13]. Building the behaviour is easier than maintaining the behaviour. Therefore, consistency is necessary in the students improving the knowledge and emotional ability so that they can get used to organize finance more effectively and efficiently.

\section{REFERENCES}

[1] International Network on Financial Education (INFE), Financial Education in Schools. OECD, 2008.

[2] Hathaway, Ian; Khatiwada, Sameer, Working Paper : Do Financial Education Programs Work? Federal Reserve Bank of Cleveland, 2008.

[3] Mandell, Lewis, The Financial Education of Young Adult - Results of the 2008 National Jump\$tart Coalition Survey of High School Seniors and College Students. Washington : The Jump\$tart Coalition For Personal Financial Literacy, 2008

[4] Yates, Dan; Ward, Chris, Financial Literacy : Examining The Knowledge Transfer Of Personal Finance From High School To College To Adulthood. American Journal of Business Education, 2011, Volume 4 Number 1, pg. 65.

[5] Yii Shih \& Chen Ke, Determinates of financial behavior : insights into consumer money attitudes and financial literacy. Springer-Verlag Berlin Heidelberg, 2014. DOI. 10.1007/s11628-013-0194-x

[6] Braunstein, S., \& Welch, C, Financial literacy: An overview of practice, research, and policy. Federal Reserve Bulletin, 2002, pg 445-457.

[7] Robb and Woodyard, Financial Knowledge and Best Practice Behavior. Journal of Financial Counseling and Planning, Volume 22, Issue 1, 2011.

[8] Svyantek, D. J, Emotional Intelligence And 
Organizational Behavior-II. The International Journal of Organizational Analysis, 2003 Vol. 11 Iss: 3, pp.167 169

[9] Paramasiva and Subramanian, Financial Management. New Delhi : New Age Internasional, 2011.

[10] Walstad et al. , The Effects of Financial Education on the Financial Knowledge of High School Students. The Journal of Consumer Affairs, Vol. 44, No. 2, 2010 ISSN 0022-0078.

[11] J.J. Xiao., Applying Behavior Theories to Financial Behavior. Handbook of Consumer Finance Research. Springer, 2008.

[12] Jorgensen, B. L., and Savla, J., Financial literacy of young adults: The importance of parental socialization. Family Relations, 2010, 59, pp. 465-478.

[13] Hogarth M, Hilgert M., Financial knowledge, experience and learning preferences: preliminary results form a new survey on financial literacy. Consum Interest Annu, 2002, vol 48:1-7

[14] Borden, L. M., Lee, S. A., Serido, J., \& Collins, D., Changing college students' financial knowledge, attitudes, and behavior through seminar participation. Journal of Family Economic Issues, 2008, 29(1), pg 2340

[15] Asaad, C.T., Financial literacy and financial behavior : Assessing knowledge and confidence. Financial Services Review 24, 205, 2015, pp 101-117.

[16] Ajzen, I., M. Fishbein, Understanding Attitudes and Predicting Social Behavior. Englewood Cliffs, New Jersey, 1980.

[17] Goleman, D., Emotional Intelligence. Jakarta: PT Gramedia Pustaka Utama, 2002.

[18] Ludigdo, U., Structuration understanding Ethics in Practice On A Public Accounting Firm. Dissertation summary. Posgraduate, Universitas Brawijaya, Malang, 2005.

[19] Hamilton et al., "It's All About Security to Me" : The Role of Environment in Youth Financial Literacy and Savings Behaviors, 2012.

[20] COHEAO., Financial Literacy in Higher Education : The Most Successful Models and Methods for Gaining Traction, 2014. 